\title{
Use of Response Surface Methodology (RSM) for Composite Blends of Low Grade Broken Rice Fractions and Full-fat Soybean Flour by a Twin-screw Extrusion Cooking Process
}

\author{
Nahemiah Danbaba ${ }^{\mathrm{a}, \mathrm{c}^{*}}$, Iro Nkama ${ }^{\mathrm{b}}$, and Mamudu Halidu Badau ${ }^{\mathrm{c}}$ \\ ${ }^{a}$ Food Technology \& Value addition Research Program, National Cereals Research Institute (NCRI) Badeggi, \\ PMB 8, Bida, Niger State, Nigeria \\ ${ }^{\mathrm{b}}$ Department of Food Science and Technology, University of Nigeria, Nsukka, Enugu State, Nigeria \\ ${ }^{\mathrm{c}}$ Department of Food Science and Technology, University of Maiduguri, Nigeria \\ ${ }^{*}$ Corresponding author \\ dnahemiah@gmail.com \\ TEL: +2348039736494
}

Received: 3 November 2017; Published online: 18 April 2019

\begin{abstract}
In this study, seventeen (17) composite blends of broken rice fractions and full-fat soybean, formulated using response surface methodology and central composite design within a range of barrel temperatures $\left(100-140^{\circ} \mathrm{C}\right)$, initial feed moisture content (15-25\%) and soybean composition (8-24\%), were extruded with a twin-screw extruder and the expansion and color indices were optimized. The results indicated a significant $(\mathrm{p}<0.05)$ effect of extrusion conditions on the responses. Fitted predictive models had coefficients of $88.9 \%, 95.7 \%, 97.3 \%, 95.4 \%$ and $95.2 \%$, respectively, for expansion index, bulk density, lightness, redness and yellowness. The p-value and lack-of-fit tests of the models could well explain the observed variability and therefore could be used to establish production setting for the twin-screw extruder. The optimum extrusion conditions were found to be $130{ }^{\circ} \mathrm{C}$ (barrel temperature), $20 \%$ (feed moisture level) and $23 \%$ feed soybean composition and optimum responses in terms of bulk density, expansion index, lightness, redness and yellowness chroma indices were $0.21 \mathrm{~g} \mathrm{~cm}^{-3}, 128.9 \%$, $17.1,3.13$ and 24.5 , respectively. This indicates that optimum conditions can be established in twinscrew extrusion cooking of broken rice fractions and full-fat soybean composite blends that can result in product of low bulk and maximum expansion with a satisfactory light yellow product color that can be used to produce products that valorize broken rice and reduce qualitative postharvest loss.
\end{abstract}

Keywords: Broken rice; Soybean; Extrusion; Response surface methodology; Optimization

\section{Introduction}

Rice (Oryza sativa L.) is an important source of food for a large number of the population in subSaharan Africa (SSA), its production and utilization is an important economic program for most governments in the region. Though production does not match consumption demand and there are huge import bills at the detriment of other critical sectors, significant improvement has been made over the last few years in increasing yield per ha in most countries. But little improvement has been recorded in the postharvest value chain of the production system (Manful, Quaye, \& Gayin, 2004; Ndindeng et al., 2015). Recently, research investment for the reduction of postharvest losses has resulted in increased interest in the utilization of rice flour from low grade broken rice fractions for the production of value added products (Chinma, Anuonye, Simon, Ohiare, \& 


\section{Nomenclature}

\author{
QPL Qualitative postharvest loss \\ SSA sub-Saharan Africa \\ RSM Response surface methodology \\ CCRD Central composite rotatable design \\ EC Extrusion cooking \\ FARO Federal agricultural research oryza \\ NCRI National Cereals Research Institute \\ EI Expansion index \\ BD Bulk density
}

$\begin{array}{ll}\text { L*}^{*} & \text { Lightness } \\ \mathrm{a}^{*} & \text { Redness } \\ \mathrm{b}^{*} & \text { Yellowness } \\ \text { D } & \text { Deviations } \\ \text { RD } & \text { Relative deviation } \\ \text { BRT } & \text { Barrel temperature } \\ \text { FMC } & \text { Feed moisture content } \\ \text { FSC } & \text { Feed soybean composition } \\ \text { DOE } & \text { Designed of experiment }\end{array}$

able products has also been advocated (Iwe, Van Zuilichem, Ngoddy, \& Ariahu, 2001) (Iwe, 2003). Extrusion cooking technology and blends of cereals and legumes have been used in several parts of Africa to produce products that are nutrient dense, consumer acceptable, with improved physical and functional qualities (Danbaba et al. 2017; Filli, 2011, 2016; Gogoi, Oswalt, \& Choudhury, 1996). During extrusion, enzymes are partially or totally inactivated, anti-nutritional factors destroyed and microbial load significantly reduced thereby improving widespread uses of legumes (Abd El-Hady, Mostafa, El-Samahy, \& El-Saies, 1998). In other parts of the world, the technology has been employed to produce foods such as breakfast cereals, snack foods, pasta products, extruded bread, modified starches, beverage powders, meat and cheese analogues, textured vegetable proteins and meat products (Abd El-Hady et al., 1998; Moore, Sanei, Hecke, \& Bouvier, 1990). The process has high versatility, efficiency, low cost of operation, and high yields with relatively no waste generation.

But to maximize the use of EC in new food product development, it is important to be able to alter process conditions to produce consumer acceptable products, improved physical and functional properties, minimized cost of production by adopting low-cost raw materials, maintained 
high quality standards and minimized losses during production (Chaiyakul et al., 2009). This can only be achieved by systematically selecting appropriate production conditions using designed experiments (DOE) (Abd El-Hady et al., 1998; Danbaba et al., 2016; Moore et al., 1990). Using DOE, Eggum, Juliano, Ibabao, and Perez (1986) and Asare, Sefa-Dedeh, Sakyi-Dawson, and Afoakwa (2004) studied the behaviour of low amylose rice flour blended with cowpea during extrusion cooking. Effects of protein content and extrusion parameters on sensory and physical properties of extruded high protein, glutinous rice-based snacks were reported by Chaiyakul et al. (2009) and Asare et al. (2004), while the effect of the addition of cowpea and groundnut on the quality of rice-based extrudates has also been reported (Asare et al., 2004). In relation to rice-soybean extrusion, Coutinho, Batista, Caliari, and Soares Junior (2013) studied the effect of moisture and extrusion temperature on broken rice blended with by-products of soybean processing, Marengo et al. (2016) and Garg and Singh (2010) used partially defatted soybean blended with rice to produce snacks, while Noguchi, Kugimiya, Haque, and Saio (1982) reported on the physical and chemical characteristics of extruded rice flour and soybean protein isolate. Omwamba and Mahungu (2014) developed extruded ready-to-eat snacks from blends of rice, sorghum and soybean. In the current study, effects of moisture, extrusion temperature and amount of full-fat soybean flour on the physical and other functional characteristics of twin screw extruded snacks were evaluated. Also, little or no information is available on the extrusion of full-fat soybean flour blended with broken parboiled rice fractions on physical indices of extruded snacks. Response surface methodology (RSM) and central composite design are mathematical techniques used for optimizing process conditions where multiple independent variables influence the response value. In food processing, the main objective of using this DOE is to locate more precise combinations of the process variables that will have the highest probability of producing food products of desired quality and also to describe interrelations between the independent variables and product quality (Colonna, 1989; Nwabueze, 2007) for sustainable quality as- surance.

Little work regarding the effects of extrusion temperature, initial feed moisture content and ratio of broken parboiled rice fractions to fullfat soybean blends on the physical and chemical properties of rice-extruded foods has been reported. Therefore, the objective of the current study is to produce extruded foods from blends of low grade broken parboiled rice fractions and full-fat roasted soybean flour, optimize the process parameters of twin-screw extruder parameters and to develop and validate mathematical models for the relationship between the response variables and the process variables using designed experiments. We believe that this will provide new sources of cheap and available raw materials, reduce qualitative rice postharvest loss and provide nutritious convenient foods for mitigating protein-energy-malnutrition in SSA.

\section{Materials and Methods}

Broken fractions of parboiled improved high amylose (28.97\%) rice variety (Federal Agricultural Research Oryza - FARO 52) and fullfat soybean (TGX-1448-2E) flour were obtained from the National Cereals Research Institute, (NCRI) Badeggi, Niger State, Nigeria. The materials were manually sorted, washed and sun dried $\left(32 \pm 2{ }^{\circ} \mathrm{C}\right)$ for $6 \mathrm{~h}$ to $10.11 \pm 0.08$ and $9.41 \pm 0.04(\mathrm{db})$ moisture content, respectively, before storing under refrigeration until required for analysis. Seventeen (17) rice-soybean formulations containing between 14 to $28 \mathrm{~kg} / 100 \mathrm{~kg}$ soybean were mixed and moisture content adjusted (Danbaba et al., 2016) to between 15 and $25 \mathrm{~g} / 100 \mathrm{~g}(\mathrm{db})$ (Table 2) by adding a given quantity of water to each sample and mixed through in a laboratory mixer for 5 min before standing for $3 \mathrm{hr}$ prior to extrusion at specified temperatures (Table 2). Preliminary experiments were conducted by extruding 8 samples with moisture and soybean contents ranging between 11.0 and $30 \%$ and 4 and $30 \%$, respectively, and extruded at a temperature of 70 to $140{ }^{\circ} \mathrm{C}$. Extruded samples that were not burnt and had expanded appreciably were selected and their processing conditions were used for the main experiments. Extrusion cooking was carried out in a twin-screw 
extruder (Model - SLG 65, Jinan Saibaino Technology Development Co. Ltd, China) powered with a 16 HP electric motor, screw speed of 300 rpm and length to diameter ratio of barrel (20:1).

\subsection{Experimental design and Extrusion Cooking}

Response surface methodology (RSM) in a fivelevel $(-\alpha,-1,0,1,+\alpha)$ central composite rotatable design (CCRD) of three variables $\left(\mathrm{X}_{1}=\right.$ barrel temperature, $\mathrm{X}_{2}=$ feed moisture content, $\mathrm{X}_{3}=$ feed soybean composition) was used (Table 1) where $\pm \alpha$ is equal to 1.682 and defines the distance of the axial runs from the design centre (Montgomery, 2001). The experimental runs consisted of 17 trials ( 8 cube points, 6 star points and 3 centre points). The expansion (EI), bulk density (BD), and colour characteristics ( $\mathrm{L}^{*}, \mathrm{a}^{*}$, $\left.\mathrm{b}^{*}\right)$ were set as the response variables $\left(\mathrm{y}_{1}, \mathrm{y}_{2}\right.$, $\mathrm{y}_{3}, \mathrm{y}_{4}$, and $\mathrm{y}_{5}$ ), respectively. Experimental data were fit to a second order polynomial response surface model, equation 1.

$Y=b_{0}+\sum_{i=1}^{n} b_{i} x_{i}+\sum_{i=1}^{n} b_{i i} x_{i}^{2}+\sum_{i=1}^{n-1} \sum_{j=i+1}^{n} b_{i j} x_{i} x_{j}+e_{i}$

where $\mathrm{Y}$ is any response variable; $n$ is the number of independent variables; $x_{i}$ and $x_{j}$ are coded variables; $b_{a}$ is the intercept; $b_{i}, b_{i i}$ and $b_{i j}$ are the linear; quadratic and interaction effects, respectively, and $e_{i}$ is the error term. The goodness of fit of the models were measured by considering the coefficient of determination $\left(\mathrm{R}^{2}\right.$ and Adjusted- $\mathrm{R}^{2}$ ), the adequacy of the quadratic models was confirmed by the analysis of variance (ANOVA) using Fishers test value (F-value) and lack-of-fit test. For statistical analysis, the natural variables values $\left(X_{i}\right)$ were transformed to coded forms according to equation 2 .

$$
x_{i}=\frac{x_{i}-x_{0}}{\delta x}
$$

Where $X_{i}=$ coded (dimensionless) value of the independent variables, $X_{0}=$ the value of $X_{i}$ at the centre point and $\delta_{i}=$ the step change in $X_{i}$ and the results are presented in Table 2. Optimization of process variables was based on the maximum values of all the responses $\left(\mathrm{EI}, \mathrm{BD}\right.$, and $\mathrm{L}^{*}$, $\left.a^{*}, b^{*}\right)$. Responses were individually assigned to different importance levels varying between 1 and 5 and optimized based on higher desirability for expansion index, $\mathrm{L}^{*}, \mathrm{~b}^{*}$ and lower desirability for bulk density and $a^{*}$. The deviations (D) and relative deviations (RD) between the experimental values and those predicted by the models for the responses at the optimal condition were calculated by equations 3 and 4 , respectively.

$$
\begin{gathered}
\text { Deviation }(\mathrm{D})=Y-\Upsilon \\
\text { Relative deviation }(\mathrm{RD})=\frac{D}{\Upsilon} \times 100
\end{gathered}
$$

where $\mathrm{Y}$ is the experimental data and $\Upsilon$ is the response predicted by the model.

\subsection{Moisture content determination}

The moisture content of feed materials and extruded samples was determined using the dry oven method with accuracy of about four digits $(0.0000 \mathrm{~g} / \mathrm{g})$.

\subsection{Bulk density (BD) and Expansion Index (EI)}

Extruded samples were analysed for EI by using the mean diameter of 10 readings and ER calculated as the ratio of diameter of the extrudates and diameter of extruder die (3mm) (AlvarezMartinez, Kondury, \& Harper, 1988). After measuring the weight per unit length of the extruded samples, the $\mathrm{BD}$ was calculated using the relationship:

$$
\mathrm{BD}=\frac{4}{\pi d^{2} L}
$$

where: $\mathrm{BD}=$ Bulk density $\left(\mathrm{g} \mathrm{cm}^{-3}\right), \mathrm{d}=$ Diameter of the extrudate $(\mathrm{cm}), \mathrm{L}=$ Length per gram of the extrudate $\left(\mathrm{cm} \mathrm{g}^{-1}\right)$.

\subsection{Color characteristics determination}

Colors of the extruded foods were measured with a Monilta Color Reader (CR-10, Minolta Co. Ltd., Tokyo, Japan) using the $\mathrm{L}^{*}, \mathrm{a}^{*}, \mathrm{~b}^{*}$ system, where the $L^{*}$ value is a measure of product 
Table 1: Codes, ranges and levels of independent variables in RSM design

\begin{tabular}{lccc}
\hline $\begin{array}{l}\text { Levels of } \\
\text { variables }\end{array}$ & $\begin{array}{c}\text { Barrel Temperature } \\
\left({ }^{\circ} \mathrm{C}, \mathrm{A}\right)\end{array}$ & $\begin{array}{c}\text { Feed Moisture content } \\
\left(\mathrm{g} 100 \mathrm{~g}^{-1} \text { sample, B }\right)\end{array}$ & $\begin{array}{c}\text { Feed Composition } \\
\left(\mathrm{g} \mathrm{100 \textrm {g } ^ { - 1 }} \text { sample, C }\right)\end{array}$ \\
\hline$-\alpha(-1.68)$ & 86.36 & 11.6 & 2.6 \\
Low $(-1)$ & 100.0 & 15.0 & 8.0 \\
Medium $(0)$ & 120.0 & 20.0 & 16.0 \\
High $(1)$ & 140.0 & 25.0 & 24.0 \\
$+\alpha(+1.68)$ & 153.6 & 28.4 & 29.5 \\
\hline \multicolumn{2}{l}{ Level of each variable was established based on preliminary extrusion trials. The distance of the axial points } \\
from the center point was \pm 1.68, and calculated from Equation $\alpha=(2 \mathrm{n})^{1 / 4}$ where $\mathrm{n}$ is the number of variables.
\end{tabular}

lightness, a chromatic color attribute of absolute black (0) to absolute white (100); a* value means mixed red-to-green color of samples ranging from negative on the red side to positive on the green side $(\mathrm{a}+=0-60$ for red and $\mathrm{a}-=0-(-60)$ for green); and the $\mathrm{b}^{*}$ value means mixed blue-toyellow colour of samples ranging from negative to positive value $(b+=0-60)$ for yellow and $b-$ $=0-(-60)$ for blue.

\subsection{Statistical analysis}

Homogeneous variance is a necessary prerequisite for linear regression model development (Filli, 2011). Therefore, to reduce the variability within the response variables, the natural variable values $\left(X_{i}\right)$ were transformed to coded forms according to equation 2. For the standardized data, one-way analysis of variance (ANOVA) was carried out to determine significant differences $(\mathrm{p} \leq 0.05)$ among the treatment combinations using response surface analysis of Minitab 16 software. Fishers Least Significance Difference (LSD) was used to check equality of variances. Results are presented as mean of three replications.

\section{Results and Discussion}

\subsection{Experimental results of extrusion exercise}

Based on the seventeen (17) composite blends of broken rice fractions and full-fat soybean flours, formulations were grouped into 5 based on the extrusion temperature, $86.0{ }^{\circ} \mathrm{C}(1), 100{ }^{\circ} \mathrm{C}(4)$, $120{ }^{\circ} \mathrm{C}(7), 140{ }^{\circ} \mathrm{C}(4)$ and $154{ }^{\circ} \mathrm{C}$ (1) (Table 2 ). These extrusion temperatures were selected based on preliminary exercise (results not presented). Digital images showing physical characteristics of snacks as they emerged from the die at steady state at each experimental condition are presented in Fig. 1 and internal macro structure in Fig. 2. There were great variations in physical appearance in terms of size, colour and puff levels and surface smoothness, therefore indicating variability due to differences in extrusion conditions. They were mostly in the form of cylindrical puffed strands with different sizes and surface textures. Samples containing lower moisture content $(8 \%)$ and extruded at temperatures above $100{ }^{\circ} \mathrm{C}$ had slightly expanded size and rougher surface than those extruded at higher moisture contents. As the moisture level increased to $24 \%$, strands became thinner and smoother surfaced. These observations are similar to those reported by Nwabueze (2007), that thin-smooth to thin-fine-smooth extrudates were obtained when African bread fruits blended with soybean and yellow maize were extruded at a higher moisture level. These indicate the need to systematically define optimum moisture level for the extrusion of rice-full-fat soybean blends for optimum product quality.

The extrudates also had varying honeycomb cellular structure of different numbers and sizes; with samples $2,5,8,10,11,12,13$ and 14 showing more and larger spaces (Fig. 2). Structurally, starch-based extruded foods have been reported to have a honeycomb cellular structure 


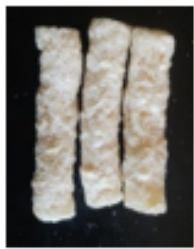

1

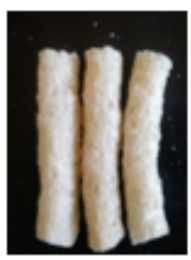

6

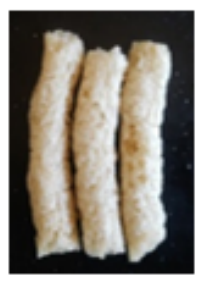

11

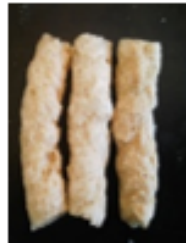

2

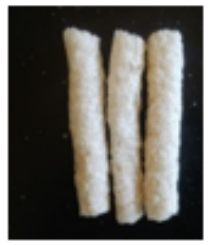

7

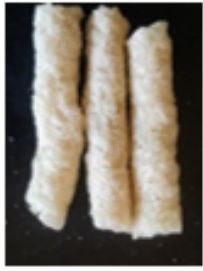

12

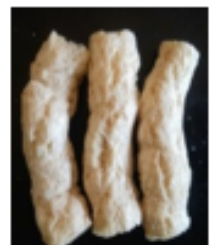

3

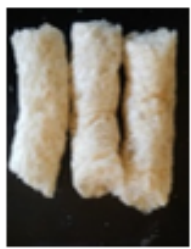

8

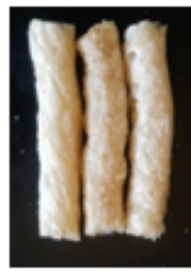

13

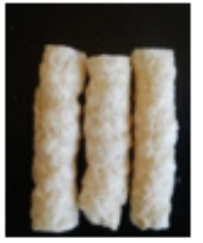

4

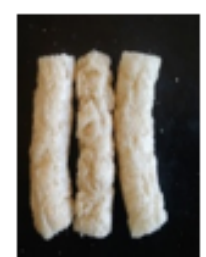

9

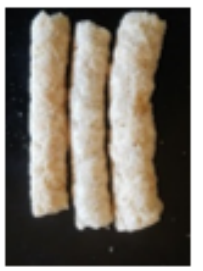

14

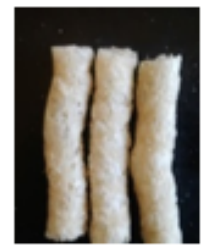

5

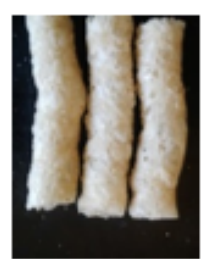

10

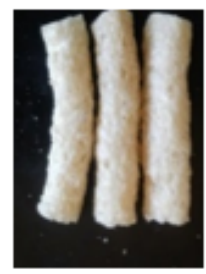

16

Figure 1: Digital images of expanded rice-full fat soy blends extruded at different conditions
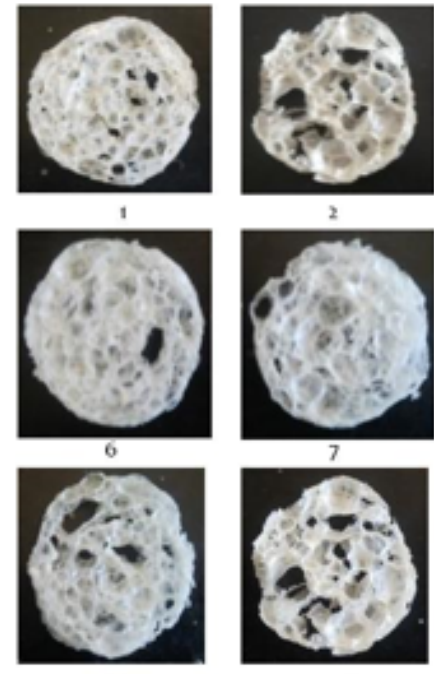

11
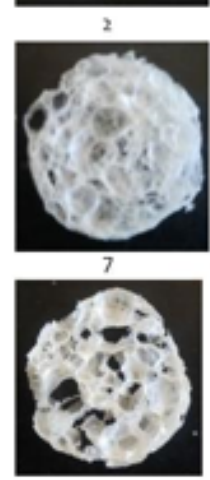

12
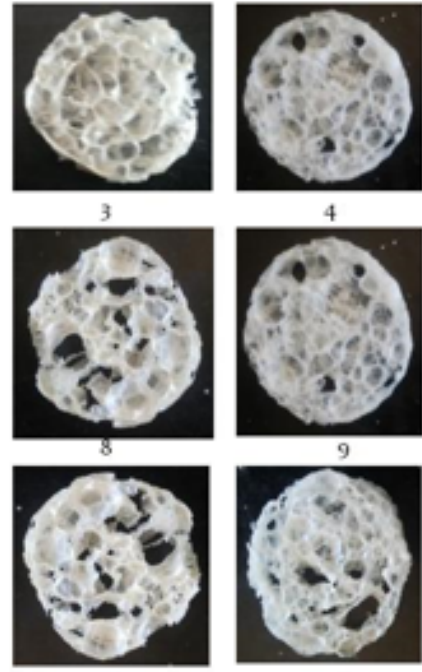

13
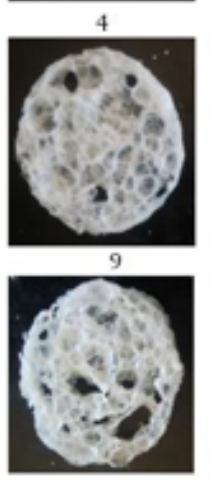

14
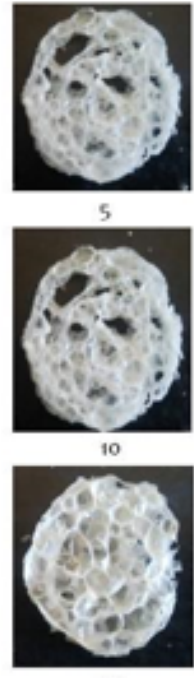

15

Figure 2: Cross section showing void spaces in rice-full fat soy blends extruded at different conditions 
(Faubion \& Hoseney, 1982; Lai, Guetzlaff, \& Hoseney, 1989) and the size and number of the cells formed have been reported to be dependent on the feed moisture content and the composition of protein and lipids in feed material, as demonstrated in this study. Similar reports were put forward by Faubion and Hoseney (1982), Lai et al. (1989), Lai and Kokini (1991).

In the reports of Agbisit, Alavi, Cheng, Herald, and Trater (2007), Yagci and Gogus (2008), it had been demonstrated that variation of feed moisture content and temperature during extrusion cooking affected the degree of expansion through transformation of the extrusion matrix, leading to differences in void space formation of puffed products. From the observed cross section of the extrudates, it could be inferred that samples 2, 5, 8, 10, 11, 12, 13 and 14 would have low breaking strength, high crispiness and better sensory acceptability.

Varying physical appearance of the extrudates in terms of color (Fig. 1) is an indication of varying response of the different formulations to different extrusion conditions and therefore clearly defines the need to locate appropriate processing conditions to have products of acceptable color. Though change in total reducing sugar variation during the process is not reported, variation in surface color of the different extruded samples may be attributed to browning reactions and pigment degradation that take place during the process (Altan, McCarthy, \& Maskan, 2008).

\subsection{Effects of individual variables and interaction on responses}

\section{Bulk density}

Table 3 shows the mean effects of the barrel temperature, initial feed moisture content and feed soybean composition on the $\mathrm{BD}$ of extruded rice full fat soybean. The experimental values for BD range between 0.035 and $0.358 \mathrm{~g} \mathrm{~cm}^{-3}$ with a mean value of $0.098 \mathrm{~g} \mathrm{~cm}^{-3}$. The deviation which measures the difference between the observed value and the predicted value, ranged between 0.021 and $0.329 \mathrm{~g} \mathrm{~cm}^{-3}$ and the relative deviation was 60.0 and $115.28 \%$ indicating wide variation between different treatments in terms of BD. It may be observed from the results that the BD increased as the feed moisture content decreased from 25 to $15 \mathrm{~g} / 100 \mathrm{~g}$ sample in runs 3 and 5 , respectively, while relative deviation, which indicates percentage deviation of the observed value from the predicted value, was highest (115.28\%) at run 6 and lowest $(60.0 \%)$ at run 3. Our observations coincide with those reported by Kulkarni and Joshi (1992) and Garg and Singh (2010) that there is a strong correlation between initial feed moisture content and BD of extrudates. As the value of the initial moisture content increased, the value of $\mathrm{BD}$ decreased and vice versa. Chang and El-Dash (2003) and Leonel, de Freitas, and Mischan (2009) also reported similar findings for extruded cassava starch. They reported that moisture content of $24-26 \%$ as observed in this study, followed by barrel temperature of $120-200{ }^{\circ} \mathrm{C}$, resulted in a significant effect on expansion and therefore bulk density. At low moisture content, there is an increased shear force in the extruder barrel which increases residence time and gelatinization of starch and subsequently increases bulk density, as observed in these results. BD is an important quality parameter in the production of extruded products as it indicates expansion at the die in all directions. In this study, barrel temperature and feed soybean content did not show significant impact on the BD (Table 3) even though several authors (Case, Hamann, \& Schwartz, 1992; Hernandez-Nava, Bello-Perez, San Martin-Martinez, HernandezSanchez, \& Mora-Escobedo, 2011) reported that $\mathrm{BD}$ value decreases when the extrusion temperature is increased due to aggravated starch gelatinization. The lack of agreement between this study and earlier reports may be due to high temperature and possible contribution of soybean oil content to the flow of the matrix in this study. Minimal addition of soybean flour was also observed to affect BD. At $8 \mathrm{~g} / 100 \mathrm{~g}$ sample of soybean flour in a blend processed at high moisture content, the highest BD was recorded (Table 3). These observations may be attributed to the behaviour of protein and oil in the formulations, since friction and shear forces during extrusion may cause extensive interlacing between protein molecules and lead to their texturization, and because high protein content promotes denser and more rigid extrudates (Hernandez-Nava et al., 
Broken rice and full-fat soybean twin extrusion cooking $\mid 21$

Table 2: Outline of experimental design with design points, coded and uncoded values of independent variables

\begin{tabular}{|c|c|c|c|c|c|c|c|}
\hline \multirow[b]{2}{*}{ Runs } & \multirow[b]{2}{*}{ Points } & \multicolumn{3}{|c|}{ Coded variables } & \multicolumn{3}{|c|}{ Natural variables } \\
\hline & & A & B & $\mathrm{C}$ & BRT & FMC & $\mathrm{FSC}$ \\
\hline \multicolumn{8}{|c|}{ Group 1 ( $100^{\circ} \mathrm{C}$ extrusion temperature) } \\
\hline 1 & Factorial point & -1 & -1 & -1 & 100 & 15 & 8 \\
\hline 3 & Factorial point & -1 & 1 & -1 & 100 & 25 & 8 \\
\hline 5 & Factorial point & -1 & -1 & 1 & 100 & 15 & 24 \\
\hline 7 & Factorial point & -1 & 1 & 1 & 100 & 25 & 24 \\
\hline \multicolumn{8}{|c|}{ Group $2\left(140^{\circ} \mathrm{C}\right.$ extrusion temperature $)$} \\
\hline 2 & Factorial point & 1 & -1 & -1 & 140 & 15 & 8 \\
\hline 4 & Factorial point & 1 & 1 & -1 & 140 & 25 & 8 \\
\hline 6 & Factorial point & 1 & -1 & 1 & 140 & 15 & 24 \\
\hline 8 & Factorial point & 1 & 1 & 1 & 140 & 25 & 24 \\
\hline \multicolumn{8}{|c|}{ Group $3\left(120^{\circ} \mathrm{C}\right.$ extrusion temperature $)$} \\
\hline 11 & Star point & 0 & -1.68 & 0 & 120 & 11.6 & 16 \\
\hline 12 & Star point & 0 & 1.68 & 0 & 120 & 28.4 & 16 \\
\hline 13 & Star point & 0 & 0 & -1.68 & 120 & 20 & 2.6 \\
\hline 14 & Star point & 0 & 0 & 1.68 & 120 & 20 & 29.5 \\
\hline 15 & Centre point & 0 & 0 & 0 & 120 & 20 & 16 \\
\hline 16 & Centre point & 0 & 0 & 0 & 120 & 20 & 16 \\
\hline 17 & Centre point & 0 & 0 & 0 & 120 & 20 & 16 \\
\hline \multicolumn{8}{|c|}{ Group $4\left(86^{\circ} \mathrm{C}\right.$ extrusion temperature $)$} \\
\hline 9 & Star point & -1.68 & 0 & 0 & 86.4 & 20 & 16 \\
\hline \multicolumn{8}{|c|}{ Group 5 ( $154^{\circ} \mathrm{C}$ extrusion temperature) } \\
\hline 10 & Star point & 1.68 & 0 & 0 & 153.6 & 20 & 16 \\
\hline
\end{tabular}

2011; Jorge et al., 2008).

\section{Expansion index}

Generally, high expansion index is a desirable property in puffed extruded foods as this typically indicates a lighter, crispier product. Expansion index has been shown to be dependent on extrusion conditions as well as blend formulations (Maskus \& S., 2015) significant factor affecting expansion ratio (Ding, Ainsworth, Tucker, \& Marson, 2005). In this study, the EI increased from $125.7 \%$ at $100{ }^{\circ} \mathrm{C}$ barrel temperature to $133.80 \%$ when the temperature increased to $120{ }^{\circ} \mathrm{C}$ with concurrent reduction in initial feed moisture content (Table 3). Hagenimana, Ding, and Fang (2006) reported reduction in EI as the moisture level increased from $16 \%$ to $22 \%$ in a twin-screw extrusion of rice flour. In our work similar observations were seen, increased EI was observed as a moisture content reduced from 25 to $20 \%$, indicating a narrow range of moisture is required for optimum product expansion of rice flour (between 16 and 22\%). Relative deviation ranging between 99.61 and $100.31 \%$ (Table 3) is also an indication of a narrow range in percentage variability between observed and predicted values. High moisture level reduces shear strength and energy input to the material resulting in decreased moisture evaporation at the die exit and therefore negatively affects expansion. In our study the use of soybean flour increased the protein level and therefore reduced the starch level in the blend which may have impeded full starch 
Table 3: Mean experimental, predicted and relative deviation results for bulk density and expansion index of extruded broken-rice full-fat soybean formulations

\begin{tabular}{|c|c|c|c|c|c|c|}
\hline \multirow[b]{2}{*}{ Runs } & \multicolumn{3}{|c|}{ Bulk density $\left(\mathrm{g} \mathrm{cm}^{-3}\right)$} & \multicolumn{3}{|c|}{ Expansion index (\%) } \\
\hline & $\mathrm{Y}$ & $\mathrm{D}$ & $\mathrm{RD}$ & $\mathrm{Y}$ & $\mathrm{D}$ & $\mathrm{RD}$ \\
\hline 1 & 0.089 & 0.092 & 103.37 & 127.8 & 128.2 & 100.31 \\
\hline 2 & 0.058 & 0.041 & 68.97 & 131.1 & 130.7 & 99.69 \\
\hline 3 & 0.035 & 0.021 & 60.00 & 125.7 & 125.8 & 100.08 \\
\hline 4 & 0.156 & 0.162 & 103.85 & 130.9 & 130.8 & 99.92 \\
\hline 5 & 0.358 & 0.329 & 91.90 & 130.7 & 130.8 & 100.08 \\
\hline 6 & 0.072 & 0.083 & 115.28 & 129.9 & 129.8 & 99.92 \\
\hline 7 & 0.075 & 0.081 & 108.00 & 131.7 & 131.6 & 99.92 \\
\hline 8 & 0.039 & 0.028 & 71.79 & 132.7 & 132.9 & 100.15 \\
\hline 9 & 0.142 & 0.146 & 102.82 & 128.8 & 128.3 & 99.61 \\
\hline 10 & 0.059 & 0.059 & 100.00 & 131.5 & 131.5 & 100.00 \\
\hline 11 & 0.147 & 0.151 & 102.72 & 128.9 & 128.9 & 100.00 \\
\hline 12 & 0.048 & 0.045 & 93.75 & 129.5 & 129.5 & 100.00 \\
\hline 13 & 0.058 & 0.062 & 106.90 & 129.8 & 129.8 & 100.00 \\
\hline 14 & 0.154 & 0.148 & 96.10 & 133.8 & 133.8 & 100.00 \\
\hline 15 & 0.059 & 0.058 & 98.31 & 133.5 & 133.5 & 100.00 \\
\hline 16 & 0.058 & 0.057 & 98.28 & 133.7 & 133.8 & 100.07 \\
\hline 17 & 0.059 & 0.056 & 94.92 & 133.6 & 133.8 & 100.15 \\
\hline Mean & 0.098 & 0.095 & 95.11 & 130.8 & 130.8 & 100.00 \\
\hline SD & 0.076 & 0.073 & 14.33 & 2.22 & 2.24 & 0.16 \\
\hline LSD & 0.012 & - & - & 2.12 & - & - \\
\hline
\end{tabular}

gelatinization with resultant reduction of expansion index from $133.8 \%$ to $125.7 \%$, representing about a $6.05 \%$ reduction. Yu, Ramaswamy, and Boye (2013) and Devi et al. (2013) in separate studies reported a reduction in expansion ratio with the addition of protein. This result indicates that the EI of extruded products depends on starch gelatinization as an increasing starchprotein ratio leads to formation of a continuous starch matrix that affects its expansion as it exits the die.

\section{Color characteristics of extruded foods}

In extruded starch-based puffed products, color is one of the important quality indicators.
Change in color may indicate extent of browning reactions such as Maillard reaction, caramelization, and degree of cooking and possibly pigment degradation that occurs during heat treatments (Altan et al., 2008; Danbaba et al., 2016). Assessment of the color components of the extruded samples showed that the value of the $\mathrm{L}^{*}$ component varied from 0.31 to 10.31 with a mean value of 5.80, as compared to 87.34 for the raw materials before extrusion, indicating a decrease in luminosity.

$\mathrm{L}^{*}$ value was highest at temperatures between $100{ }^{\circ} \mathrm{C}$ and $120{ }^{\circ} \mathrm{C}$, feed moisture levels of 15 to $20 \%$ and soybean composition of 8 to $16 \%$ (Table 3). At moisture content less than $20 \%$ and extrusion temperature greater than $100{ }^{\circ} \mathrm{C}$, there was 
darkening of extruded starch mainly due to increased residence time and viscosity, i.e lesser $\mathrm{L}^{*}$ value. Our results were in agreement with those of Gutkoski and El-Dash (1999), who reported that with initial moisture content of 17 to $24 \%$ and barrel temperature of $90^{\circ} \mathrm{C}$ to $150{ }^{\circ} \mathrm{C}$, luminosity decreased linearly with barrel temperature in an extruded oat product. The deviation range of 0.06 to 10.32 and relative deviation of 19.35 to $124.46 \%$ is an indication of variation among treatments in terms of this parameter.

The chroma $\mathrm{a}^{*}$ (redness) values ranged from 0.73 to 5.21 , and the deviation and relative deviation were between $0.92,59.13$ and $81.3,140.91 \%$ which indicates slight variability in this color parameter during extrusion cooking considering the observed value can vary from -60 to +60 , and low RD indicates slight variability in percentage. The highest value occurred at a temperature range of 120 to $140{ }^{\circ} \mathrm{C}$, feed moisture level of 15 to $20 \%$ and feed soybean content of 8 to $16 \%$ (runs 2 and 17) (Table 2 and 4) indicating the need to optimize the process variables to locate the most suitable point that will give acceptable quality in terms of this parameter. Responses of the $\mathrm{b}^{*}$ color index, which represents transition from blue to yellow on the chroma chart, varied according to the treatment (from 13.13 to 28.80) indicating that all samples had a yellow color. The increase of barrel temperature from 120 to $154^{\circ} \mathrm{C}$ (runs 13 and 10) (Table 2 and 4) increased b* color intensity at $20 \%$ moisture content and $2.6 \%$ soybean content of the feed materials. High moisture level resulted in brighter products since increase in moisture decreases the residence time, providing less non-enzymatic darkening of extruded products (Badrie \& Mellowes, 1991).

\subsection{Fitting and validating RSM models for optimizing production processes}

RSM models to optimize the relationship between extrusion cooking variables and response variables in terms of expansion and color indices are outlined in the regression model equation 4-8. The coefficients with only one factor $\left(\mathrm{X}_{1}\right.$, $\mathrm{X}_{2}$ and $\mathrm{X}_{3}$ ) represent the effect of that single factor, while those with two factors $\left(\mathrm{X}_{1} \mathrm{X}_{2}\right.$,
$\left.\mathrm{X}_{1} \mathrm{X}_{3}, \mathrm{X}_{2} \mathrm{X}_{3}\right)$ are the interaction terms and $X_{1}^{2}, X_{2}^{2}$ and $X_{3}^{2}$ are the square terms. Positive or negative coefficients indicate synergistic or antagonistic contributions to the observed responses. The results of ANOVA performed on the RSM models to assess the significance of the linear, quadratic and interactive effects of the independent variables on the dependent variables are presented in Tables 5 .

From equation 6 , it is clear that $\mathrm{X}_{1}$ and $\mathrm{X}_{2}$ negatively affected bulk density at both linear and quadratic levels, while only $\mathrm{X}_{1} \mathrm{X}_{3}$ and $\mathrm{X}_{2} \mathrm{X}_{3}$ reduced this response at the interaction level. All three factors positively impacted expansion at linear levels and negatively affected expansion index at square levels (equation 7 ). This demonstrated the inverse relationship between bulk density and expansion index of extrudate under linear and square processing conditions. Equation 8 indicated that increasing barrel temperature (X2) resulted in increased lightness at linear and interaction levels. X1 and X3 linearly affected redness positively and all the factors positively affected this factor at square levels (equation 9). Temperature only seemed to negatively affect the yellow color index at both linear and square levels, but interactions between X1X3 and X2X3 negatively impacted yellow color formation (equation 10).

$$
\begin{aligned}
& \text { Bulk density }\left(\mathrm{g} \mathrm{cm}^{-3}\right)=0.110-0.027 X_{1}- \\
& 0.027 X_{2}+0.029 X_{3}-0.002 X_{1}^{2}-0.007 X_{2}^{2}+ \\
& 0.001 X_{3}^{2}+0.053 X_{1} X_{2}-0.053 X_{1} X_{3}- \\
& 0.043 X_{2} X_{3} \\
& \left(R^{2}=0.957, R_{a d j}^{2}=0.946\right)
\end{aligned}
$$

Expansion index $=1.324+0.012 X_{1}+0.010 X_{2}+$ $0.014 X_{3}-0.008 X_{1}^{2}-0.004 X_{2}^{2}-0.004 X_{3}^{2}+$ $0.004 X_{1} X_{2}-0.007 X_{1} X_{3}+0.012 X_{2} X_{3}$ $\left(R^{2}=0.889, R_{a d j .}^{2}=0.860\right)$

Lightness $\left(\mathrm{L}^{*}\right)=16.773-2.021 X_{1}+0.132 X_{2}-$

$$
\begin{aligned}
& 0.447 X_{3}-1.135 X_{1}^{2}+0.173 X_{2}^{2}-0.330 X_{3}^{2}+ \\
& 0.625 X_{1} X_{2}+0.649 X_{1} X_{3}-1.282 X_{2} X_{3} \\
& \left(R^{2}=0.973, R_{a d j .}^{2}=0.966\right)
\end{aligned}
$$


Table 4: Mean experimental, predicted and relative deviation results for color characteristics of extruded broken-rice full-fat soybean formulations

\begin{tabular}{lccccccccc}
\hline & \multicolumn{3}{c}{ Lightness $\left(\mathrm{L}^{*}\right)$} & \multicolumn{3}{c}{ Redness $\left(\mathrm{a}^{*}\right)$} & \multicolumn{3}{c}{ Yellowness $\left(\mathrm{b}^{*}\right)$} \\
Runs & $\mathrm{Y}$ & $\mathrm{D}$ & $\mathrm{RD}$ & $\mathrm{Y}$ & $\mathrm{D}$ & $\mathrm{RD}$ & $\mathrm{Y}$ & $\mathrm{D}$ & $\mathrm{RD}$ \\
\hline 1 & 10.31 & 10.32 & 100.10 & 0.9 & 0.97 & 107.78 & 16.01 & 15.91 & 99.38 \\
2 & 3.67 & 3.55 & 96.73 & 5.21 & 5.13 & 98.46 & 23.26 & 23.41 & 100.64 \\
3 & 7.13 & 6.92 & 97.05 & 1.57 & 1.54 & 98.09 & 21.0 & 20.97 & 99.86 \\
4 & 2.23 & 2.42 & 108.52 & 2.3 & 1.87 & 81.30 & 22.1 & 21.98 & 99.46 \\
5 & 5.51 & 5.45 & 98.91 & 0.75 & 0.92 & 122.67 & 23.7 & 234.97 & 991.43 \\
6 & 1.39 & 1.73 & 124.46 & 3.64 & 3.41 & 93.68 & 26.49 & 26.67 & 100.68 \\
7 & 6.73 & 6.98 & 103.71 & 3.2 & 3.02 & 94.38 & 17.17 & 17.17 & 100.00 \\
8 & 5.4 & 5.52 & 102.22 & 2.01 & 1.68 & 83.58 & 13.13 & 13.38 & 101.90 \\
9 & 6.9 & 6.97 & 101.01 & 2.63 & 2.49 & 94.68 & 25.5 & 25.49 & 99.96 \\
10 & 0.31 & 0.06 & 19.35 & 4.35 & 4.86 & 111.72 & 28.8 & 28.6 & 99.31 \\
11 & 7.16 & 7.12 & 99.44 & 2.61 & 2.53 & 96.93 & 23.7 & 23.48 & 99.07 \\
12 & 7.6 & 7.46 & 98.16 & 1.1 & 1.55 & 140.91 & 16.55 & 16.56 & 100.06 \\
13 & 6.42 & 6.56 & 102.18 & 1.02 & 1.17 & 114.71 & 14.78 & 14.92 & 100.95 \\
14 & 5.38 & 5.06 & 94.05 & 0.73 & 0.95 & 130.14 & 14.81 & 14.47 & 97.70 \\
15 & 8.41 & 8.44 & 100.36 & 1.36 & 1.3 & 95.59 & 23.12 & 23.16 & 100.17 \\
16 & 10.31 & 10.32 & 100.10 & 0.9 & 0.97 & 107.78 & 16.01 & 15.91 & 99.38 \\
17 & 3.67 & 3.55 & 96.73 & 5.21 & 5.13 & 98.46 & 23.26 & 23.41 & 100.64 \\
Mean & 5.80 & 5.79 & 96.65 & 2.32 & 2.32 & 104.17 & 20.55 & 32.97 & 152.39 \\
SD & 2.84 & - & - & 1.53 & - & - & 4.75 & - & - \\
LSD & 1.04 & - & - & 0.21 & - & - & 2.02 & - & - \\
\hline
\end{tabular}

$\mathrm{Y}=$ experimental results, $\mathrm{D}=$ deviation which represent fitted value, $\mathrm{RD}=$ Relative deviation, $\mathrm{SD}=\mathrm{Standard}$ deviation. Equation on which responses are predicted $=\beta_{0}+\beta_{1} \mathrm{X}_{1}+\beta_{2} \mathrm{X}_{2}+\beta_{3} \mathrm{X}_{3}+\beta_{11} \mathrm{X}_{1}^{2}+\beta_{22} \mathrm{X}_{2}^{2}+\beta_{33} \mathrm{X}_{3}^{2}+\beta_{12} \mathrm{X}_{1} \mathrm{X}_{2}+$ $\beta_{13} \mathrm{X}_{1} \mathrm{X}_{3}+\beta_{23} \mathrm{X}_{2} \mathrm{X}_{3}$. Mean in the same column having differences greater than LSD are significantly different $(\mathrm{p} \leq 0.05)$ according to Fishers Least Significance Test.

$$
\begin{aligned}
& \text { Redness }\left(\mathrm{a}^{*}\right)=2.521+0.431 X_{1}-0.162 X_{2}+ \\
& 0.051 X_{3}-1.135 X_{1}^{2}+0.368 X_{2}^{2}+0.154 X_{3}^{2}+ \\
& 0.001 X_{1} X_{2}-0.493 X_{1} X_{3}-0.364 X_{2} X_{3} \\
& \left(R^{2}=0.954, R_{a d j .}^{2}=0.942\right)
\end{aligned}
$$

Yellowness $\left(\mathrm{b}^{*}\right)=22.060+0.0936 X_{1}-0.170 X_{2}+$ $1.770 X_{3}-0.720 X_{1}^{2}+0.602 X_{2}^{2}-1.652 X_{3}^{2}+$ $1.265 X_{1} X_{2}-0.493 X_{1} X_{3}-1.945 X_{2} X_{3}$ $\left(R^{2}=0.952, R_{a d j .}^{2}=0.939\right)$

It is clear from equations $4-8$ and probability values (Table 5), that the bulk density, expansion indices and color parameters were all significantly $(\mathrm{p}<0.05)$ affected by varying barrel temperature, initial feed moisture content and feed soybean composition as predicted by the models. The $R^{2}$ and adjusted $R^{2}$ values were $R^{2}=$ $0.957, \mathrm{R}_{a d j .}^{2}=0.946$ for bulk density, $\mathrm{R}^{2}=0.889$, $\mathrm{R}_{\text {adj. }}^{2}=0.860$ (expansion index), $\mathrm{R}^{2}=0.886$, $\mathrm{R}_{a d j .}^{2}=0.870\left(\mathrm{~L}^{*}\right), \mathrm{R}^{2}=0.954, \mathrm{R}_{a d j .}^{2}=0.942$ (redness) and $\mathrm{R}^{2}=0.952, \mathrm{R}_{a d j}^{2}=0.939$ (yellowness) (equation 4-8, respectively). The $\mathrm{R}^{2}$ and adjusted $\mathrm{R}^{2}$ defines the proportion of variability in the observed responses which are accounted for by the fitted models (Danbaba et al., 2016; Filli, 2011; Singh, Sekhon, \& Singh, 2007), and the closer the values are to unity, the better the empirical model fits the experimental data (Lee \& Wang, 1997), thus, the results of this study suggest that the models appropriately defined the process behaviour by explaining $94.6 \%, 86.0 \%, 87.0 \%, 94.2 \%$ and $93.9 \%$ of 
Broken rice and full-fat soybean twin extrusion cooking $\mid 25$

Table 5: Analysis of variance (ANOVA) and lack-of-fit p-values, R2 and adjusted R2 and estimates of the coefficients of the second-order response surface

\begin{tabular}{|c|c|c|c|c|c|c|c|c|c|c|}
\hline & \multicolumn{2}{|c|}{ Expansion index } & \multicolumn{2}{|c|}{ Bulk density } & \multicolumn{2}{|c|}{ Lightness $\left(\mathrm{L}^{*}\right)$} & \multicolumn{2}{|c|}{ Redness $\left(a^{*}\right)$} & \multicolumn{2}{|c|}{ Yellowness $\left(b^{*}\right)$} \\
\hline & Coefficient & p-value & Coefficient & $\mathrm{p}$-value & Coefficient & $\mathrm{p}$-value & Coefficient & $\mathrm{p}$-value & Coefficient & $\mathrm{p}$-value \\
\hline$b_{0}$ & 1.324 & 0.000 & 0.110 & 0.003 & 16.773 & 0.000 & 2.521 & 0.022 & 22.06 & 0.017 \\
\hline Linear & & & & & & & & & & \\
\hline$b_{1}$ & 0.012 & 0.001 & -0.027 & 0.001 & -2.021 & 0.002 & 0.431 & 0.000 & 0.094 & 0.002 \\
\hline$b_{2}$ & 0.010 & 0.002 & -0.027 & 0.002 & 0.132 & 0.000 & -0.162 & 0.000 & -2.093 & 0.000 \\
\hline$b_{3}$ & 0.014 & 0.000 & 0.029 & 0.000 & -0.447 & 0.000 & 0.051 & 0.001 & -0.170 & 0.010 \\
\hline Quadratic & & & & & & & & & & \\
\hline $\mathrm{b}_{2}^{1}$ & -0.008 & 0.051 & -0.002 & 0.001 & -1.135 & 0.003 & 0.368 & 0.002 & 1.770 & 0.000 \\
\hline $\mathrm{b}_{2}^{2}$ & -0.004 & 0.000 & -0.007 & 0.004 & 0.173 & 0.012 & 0.154 & 0.003 & -0.720 & 0.000 \\
\hline$b_{2}^{3}$ & -0.004 & 0.001 & 0.001 & 0.008 & -0.330 & 0.017 & 0.001 & 0.021 & -0.602 & 0.016 \\
\hline Interaction & & & & & & & & & & \\
\hline$b_{1} b_{2}$ & 0.004 & 0.002 & 0.053 & 0.027 & 0.625 & 0.001 & -0.493 & 0.002 & -1.652 & 0.000 \\
\hline$b_{1} b_{3}$ & -0.007 & 0.001 & -0.053 & 0.001 & 0.649 & 0.002 & -0.364 & 0.000 & -1.265 & 0.001 \\
\hline$b_{2} b_{3}$ & 0.012 & 0.001 & -0.043 & 0.000 & 1.282 & 0.000 & 0.031 & 0.000 & -1.945 & 0.003 \\
\hline $\mathrm{R}^{2}$ & 0.889 & - & 0.957 & - & 0.973 & - & 0.954 & - & 0.952 & - \\
\hline $\mathrm{R}_{\text {ajusted }}^{2}$ & 0.860 & - & 0.946 & - & 0.966 & - & 0.942 & - & 0.939 & - \\
\hline Lack-of-fit & 0.710 & - & 0.071 & - & 0.319 & - & 0.082 & - & 0.982 & - \\
\hline
\end{tabular}

the variations observed in bulk density, expansion index, lightness, redness and yellowness, respectively. Additionally, the p-values of lack-offit test for the models were not significant ( $\mathrm{p}$ $<0.05)$, which indicates that the models can be used for the prediction of the observed responses within the experimental domain studied. Yagci and Gogus (2008) were of the opinion that with significant probability values $(\mathrm{p}<$ 0.001) and non-significant lack-of-fit tests, fitted second-order models could be adequately used as predictor models, regardless of low coefficients of determination. It is clear and appropriate therefore to conclude that the developed models adequately approximate the response variables considered in this study and can be used satisfactorily for the prediction of any value of the responses within the defined experimental range.

\section{Optimization process variables}

In this study, simultaneous numerical optimization of the independent and dependent variables was conducted using a Minitab response optimizer. To meet the intended target requirement placed on each response variable and independent factor in this experiment, a goal was set for each independent and dependent variable. An- uar, Adnan, Saat, Aziz, and Taha (2013), Gupta, Verma, Jain, and Jain (2014) and Danbaba et al. (2016) reported that for locating optimum conditions using numerical methods, there was a need to set goals, which may either be none, maximum, minimum, target or range for both response and independent variables that could be combined into one desirable function. In this work, the barrel temperature, feed moisture content and feed soybean composition were all set within range (100 to $140{ }^{\circ} \mathrm{C} ; 15$ to $25 \% ; 8$ to $24 \%$ ) as defined by the preliminary study (Table 1), while the goal for the response variables of bulk density, expansion index and lightness chroma levels were set at maximum, and $\mathrm{a}^{*}$ and b* set at minimum (Table 6). Anuar et al. (2013) reported that when goal was set at 5 , the response target objective was to meet the objective of getting response at a maximum level.

Results of the numerical optimization therefore indicated that the optimum extrusion variables were $130{ }^{\circ} \mathrm{C}$ (barrel temperature), $20 \%$ (feed moisture level) and 23\% (feed soybean composition) (Table 6), while optimum responses in terms of bulk density, expansion index, lightness, redness and yellowness indices were $0.21 \mathrm{~g} \mathrm{~cm}^{-3}$, $128.9 \%, 17.1,3.13$ and 24.5 , respectively. This indicates that the optimum conditions can be established in twin-screw extrusion cooking of low- 
Table 6: Constraints and goals applied to locate optimum conditions for processing parameters and responses for rice-full-fat soybean based extruded foods

\begin{tabular}{lccccc}
\hline Variables & Goal & Lower limit & Upper limit & Importance & Optimum \\
\hline Extrusion variables & & & & & \\
Barrel Temperature $\left({ }^{\circ} \mathrm{C}\right)$ & In range & 100 & 140 & 3 & 130 \\
Moisture content $(\%$ w.b) & In range & 8 & 24 & 3 & 20 \\
Blend composition $(\%)$ & In range & 15 & 25 & 3 & 23 \\
Response variables & & & & & \\
Bulk density $\left(\mathrm{gcm}^{-3}\right)$ & Maximize & 0.035 & 0.36 & 5 & 0.21 \\
Expansion index $(\%)$ & Maximize & 125.7 & 133.8 & 5 & 128.9 \\
Lightness (L*) & Maximize & 10.3 & 18.3 & 3 & 17.1 \\
Redness ( $\left.\mathrm{a}^{*}\right)$ & Minimize & 0.75 & 4.35 & 3 & 3.13 \\
Yellowness (b*) & Minimize & 13.1 & 28.8 & 3 & 24.5 \\
\hline
\end{tabular}

grade fractions of parboiled rice and full-fat soybean composite blends which can result in product of low bulk and maximum expansion with satisfactory light yellow color.

\section{Conclusions}

Based on the RSM models proposed, optimum extrusion cooking conditions for broken rice fractions and full-fat soybean were established at $130{ }^{\circ} \mathrm{C}, 20 \mathrm{~g}$ water per $100 \mathrm{~g}$ sample and $23 \mathrm{~g}$ soybean per $100 \mathrm{~g}$ rice with overall desirability conditions of 0.996 , while the response variables were all desirable. The optimum formulation expands favorably at the die (128.9\%), produces light weight product with desirable light yellow color similar to commercial extruded breakfast or complimentary cereals. Based on this result, more alternative raw materials are at the disposal of food industries in Nigeria and indeed Sub-Saharan African countries that are recommended to produce expanded instant foods which could be blended with legumes to improve nutrition and reduce malnutrition and even produce products for food aid among migrant communities.

\section{Acknowledgements}

Financial support received from Africa Rice Centre (AfricaRice) and Global Affairs Canada (GAC) under the Project number A034968 on
"Enhancing food security in Africa through the improvement of rice postharvest handling, marketing and the development of new rice- based products" is highly appreciated.

\section{References}

Abd El-Hady, E. A., Mostafa, G. A., El-Samahy, S. K., \& El-Saies, I. A. (1998). Production of high fiber corn extrudates. Journal of Agricultural Science Mansoura Univ. 23(3), 1231-1245.

Agbisit, R., Alavi, S., Cheng, E., Herald, T., \& Trater, A. (2007). Relationships between microstructure and mechanical properties of cellular cornstarch extrudates. Journal of Texture Studies, 38(2), 199-219. doi:10. $1111 / \mathrm{j} .1745-4603.2007 .00094 . x$

Altan, A., McCarthy, K. L., \& Maskan, M. (2008). Twin-screw extrusion of barley-grape pomace blends: Extrudate characteristics and determination of optimum processing conditions. Journal of Food Engineering, 89(1), 24-32. doi:10.1016/j . jfoodeng.2008.03.025

Alvarez-Martinez, L., Kondury, K. P., \& Harper, J. M. (1988). A general model for expansion of extruded products. Journal of Food Science, 53(2), 609-615. doi:10.1111/j . 1365-2621.1988.tb07768.x. eprint: https: / / onlinelibrary. wiley. com / doi / pdf / 10 . 1111/j.1365-2621.1988.tb07768.x 
Anuar, N., Adnan, A. F. M., Saat, N., Aziz, N., \& Taha, R. M. (2013). Optimization of extraction parameters by using response surface methodology, purification, and identification of anthocyanin pigments in melastoma malabathricum fruit. Scientific World Journal. doi:10.1155/2013/ 810547

Asare, E. K., Sefa-Dedeh, S., Sakyi-Dawson, E., \& Afoakwa, E. O. (2004). Application of response surface methodology for studying the product characteristics of extruded rice-cowpea-groundnut blends. International Journal of Food Sciences and Nutrition, 55(5), 431-439. doi:10.1080/ 09637480400003238

Asefa, B., \& Melaku, E. T. (2017). Evaluation of impact of some extrusion process variables on chemical, functional and sensory properties of complimentary food from blends of finger millet, soybean and carrot. African Journal of Food Science, 11(9), 302-309. doi:10.5897/AJFS2017.1608

Badrie, N., \& Mellowes, W. A. (1991). Effect of extrusion variables on cassava extrudates. Journal of Food Science, 56, 1334-1337. doi:10.1111/j.1365-2621.1991.tb04766.x

Case, S. E., Hamann, D. D., \& Schwartz, S. J. (1992). Effect of starch gelatinization on physical-properties of extruded wheat-based and corn-based products. $\mathrm{Ce}$ real Chemistry, 69(4), 401-404.

Chaiyakul, S., Jangchud, K., Jangchud, A., Wuttijumnong, P., \& Winger, R. (2009). Effect of extrusion conditions on physical and chemical properties of high protein glutinous rice-based snack. $L W T$ - Food Science and Technology, 42(3), 781-787. doi:10 . 1016/j.lwt.2008.09.011

Chang, Y. K., \& El-Dash, A. A. (2003). Effects of acid concentration and extrusion variables on some physical characteristics and energy requirements of cassava starch. Brazilian Journal of Chemical Engineering, 20(2), 129-137. doi:10.1590 / S010466322003000200006

Chinma, C. E., Anuonye, J. C., Simon, O. C., Ohiare, R. O., \& Danbaba, N. (2015). Effect of germination on the physicochemical and antioxidant characteristics of rice flour from three rice varieties from nigeria. Food Chemistry, 185, 454-458. doi:10.1016/j . foodchem.2015.04.010

Colonna, P. (1989). Extrusion cooking of starch and starchy products. Extrusion Cooking, 247-319.

Coutinho, L. S., Batista, J. E. R., Caliari, M., \& Soares Junior, M. S. (2013). Optimization of extrusion variables for the production of snacks from by-products of rice and soybean. Food Science and Technology, 33(4), 705-712.

Danbaba, N., Nkama, I., \& Badau, M. (2016). Application of response surface methodology (rsm) for the production and optimization of extruded instant porridge from broken rice fractions blended with cowpea. International Journal of Nutrition and Food Sciences, 5, 105-116. doi:10.11648/j.ijnfs. 20160502.13

Danbaba, N., Nkama, I., Bada, M. H., Gbenyi, D. I., Idakwo, P. Y., Ndindeng, S. A., \& Moreira, J. (2017). Multiple parameter optimization of hydration characteristics and proximate compositions of rice-soybean extruded foods. Open Access Library Journal, $4(02), 1$.

Devi, N. L., Shobha, S., Tang, X., Shaur, S. A., Dogan, H., \& Alavi, S. (2013). Development of protein-rich sorghum-based expanded snacks using extrusion technology. International Journal of Food Properties, 16(2), 263-276. doi:10 . 1080/10942912. 2011.551865

Ding, Q.-B., Ainsworth, P., Tucker, G., \& Marson, H. (2005). The effect of extrusion conditions on the physicochemical properties and sensory characteristics of rice-based expanded snacks. Journal of Food Engineering, 66 (3), 283-289. doi:10.1016/j. jfoodeng.2004.03.019

Eggum, B. O., Juliano, B. O., Ibabao, M. G. B., \& Perez, C. M. (1986). Effect of extrusion cooking on nutritional value of rice flour. Food Chemistry, 19(3), 235-240. doi:https: //doi.org/10.1016/0308-8146(86)90073-7

Faubion, J. M., \& Hoseney, R. C. (1982). High temperature short time extrusion cooking of wheat and flour II.Effect of moisture content and flour type on extrudate proper- 
ties. Cereal Chemistry, 59(6), 329-333. Retrieved from http://.aacnet.org

Filli, K. (2011). Application of response surface methodology for the study of composition of extruded millet-cowpea mixtures for the manufacture of fura: A Nigerian food. African Journal of Food Science, 5(16), 884-896.

Filli, K. (2016). Physicochemical properties of sorghum malt and bambara groundnut based extrudates. Journal of Food Science and Technology Nepal, 9, 55-65. doi:10 . 3126/jfstn.v910.12075

Garg, S. K., \& Singh, D. S. (2010). Optimization of extrusion conditions for defatted soyrice blend extrudates. Journal of Food Science and Technology-mysore, 47(6), 606612. doi:10.1007/s13197-010-0117-y

Gogoi, B. K., Oswalt, A. J., \& Choudhury, G. S. (1996). Reverse screw element(s) and feed composition effects during twin-screw extrusion of rice flour and fish muscle blends. Journal of Food Science, 61(3), 5990-595. doi:10.1111/j.1365-2621.1996.tb13165.x

Gupta, K., Verma, M., Jain, P., \& Jain, M. (2014). Process optimization for producing cowpea added instant kheer mix using response surface methodology. Journal of Nutrition Health and Food Engineering, 1(5), 00030. doi:10.15406/jnhfe.2014.01. 00030

Gutkoski, L. C., \& El-Dash, A. A. (1999). Effect of extrusion process variables on physical and chemical properties of extruded oat products. Plant Foods for Human $\mathrm{Nu}$ trition, 54 (4), 315-325. doi:10.1023 / A : 1008101209353

Hagenimana, A., Ding, X., \& Fang, T. (2006). Evaluation of rice flour modified by extrusion cooking. Journal of Cereal Science, 43(1), 38-46. doi:10.1016/j.jcs.2005.09.003

Hernandez-Nava, R. G., Bello-Perez, L. A., San Martin-Martinez, E., Hernandez-Sanchez, H., \& Mora-Escobedo, R. (2011). Effect of extrusion cooking on the functional properties and starch components of lentil/banana blends: Response surface analysis. Revista Mexicana De Ingenieria Quimica, 10(3), 409-419.
Iwe, M. O. (2003). The science and technology of soybean. Rejoint Communication Services Ltd, Uwani, Enugu, Nigeria.

Iwe, M. O., Van Zuilichem, D. J., Ngoddy, P. O., \& Ariahu, C. C. (2001). Residence time distribution in a single-screw extruder processing soy-sweet potato mixtures. $L W T$ Food Science and Technology, 34(7), 478483. doi:10.1006/fstl.2001.0785

Jorge, R.-R., Alma, M.-A., Silvina, D., Rolando, G., David, B.-A., \& Luis, C.-G. (2008). Extrusion of a hard-to-cook bean (phaseolus vulgaris 1.) and quality protein maize (zea mays l.) flour blend. LWT - Food Science and Technology, 41(10), 1799-1807. doi:10. 1016/j.lwt.2008.01.005

Kadan, R. S., Bryant, R. J., \& Pepperman, A. B. (2003). Functional properties of extruded rice flours. Journal of Food Science, 68(5), 1669-1672. doi:10.1111/j.1365-2621.2003. tb12311.x

Kulkarni, S. D., \& Joshi, K. C. (1992). Potato starch soy blends: Possible effects of starch properties on few aspects of end products. Indian Food Packer, 46, 38-38.

Lai, C. S., Guetzlaff, J., \& Hoseney, R. C. (1989). Role of sodium-bicarbonate and trapped air in extrusion. Cereal Chemistry, 66(2), 69-73.

Lai, L. S., \& Kokini, J. L. (1991). Physicochemical changes and rheological properties of starch during extrusion (a review). Biotechnology Progress, 7(3), 251-266. doi:10 . 1021/bp00009a009

Lee, C. L., \& Wang, W. L. (1997). Biological Statistics (Beijing, People's Republic of China, Ed.). Science Press.

Leonel, M., de Freitas, T. S., \& Mischan, M. M. (2009). Physical characteristics of extruded cassava starch. Scientia Agricola, 66 (4), 486-493. doi:10.1590/S010390162009000400009

Manful, J. T., Quaye, W., \& Gayin, J. (2004). Feasibility study on parboiled rice quality improvement programme in some selected communities around tamale in the northern region of ghana. Report for the Food Security and Rice Producers Organization Project (FSRPOP), CSIRFRI/RE/MJT/2004/020. 
Broken rice and full-fat soybean twin extrusion cooking $\mid 29$

Marengo, M., Akoto, H., Zanoletti, M., Carpen, A., Buratti, S., Benedetti, S., ... Saalia, F., et al. (2016). Soybean-enriched snacks based on African rice. Foods, 5(2), 38.

Maskus, H., \& S., A. (2015). Extrusion processing and evaluation of an expanded, puffed pea snack product. Journal of Nutrition and Food Sciences, 5, 378. doi:10.4172/ 2155-9600.1000378

Montgomery, D. C. (2001). Design and analysis of experiments. John Wiley and Sons, Inc., New York.

Moore, D., Sanei, A., Hecke, E., \& Bouvier, J. M. (1990). Effect of ingredients on physical/structural properties of extrudates. Journal of Food Science, 55(5), 1383-1387. Retrieved from 10.1111/j.1365-2621.1990. tb03942.x

Ndindeng, S. A., Manful, J., Futakuchi, K., Moreira, J., Graham Acquaah, S., Oussou, P., ... Candia, A. (2015). The first international congress on postharvest loss prevention, developing measurement approaches and intervention strategies for smallholders. In Rome, Italy, October 4-7, 2015 (pp. 31-33).

Noguchi, A., Kugimiya, W., Haque, Z., \& Saio, K. (1982). Physical and chemical characteristics of extruded rice flour and rice flour fortified with soybean protein isolate. Journal of Food Science, 47(1), 240-245. doi:10. 1111/j.1365-2621.1982.tb11069.x

Nwabueze, T. U. (2007). Nitrogen solubility index and amino acid profile of extruded african breadfruit (t. africana) blends. Nigerian Food Journal, 25(1), 2335. doi:10.4314/nifoj.v25i1.33651

Omwamba, M., \& Mahungu, S. M. (2014). Development of a protein-rich ready-to-eat extruded snack from a composite blend of rice, sorghum and soybean flour. Food and Nutrition Sciences, 5(14), 1309. doi:10 . 4236/fns.2014.514142

Singh, B., Sekhon, K. S., \& Singh, N. (2007). Effects of moisture, temperature and level of pea grits on extrusion behaviour and product characteristics of rice. Food Chemistry, 100(1), 198-202. doi:10.1016/j.foodchem. 2005.09.042
Yagci, S., \& Gogus, F. (2008). Response surface methodology for evaluation of physical and functional properties of extruded snack foods developed from food-by-products. Journal of Food Engineering, 86(1), 122132. doi:10.1016/j.jfoodeng.2007.09.018

Yu, L., Ramaswamy, H. S., \& Boye, J. (2013). Protein rich extruded products prepared from soy protein isolate-corn flour blends. LWT - Food Science and Technology, 50(1), 279-289. doi:10.1016/j. lwt. 2012. 05.012 